\title{
Tapping into the Influence of Keratinocyte Allografts and Biocenosis on Healing of Chronic Leg Ulcers: Split-Ulcer Controlled Pilot Study
}

\author{
Philippe Paquet, MD, PhD, Pascale Quatresooz, MD, Catherine Braham, MD, and Gérald E. Piérard, \\ $\mathrm{MD}, \mathrm{PHD}$
}

Department of Dermatopathology, University Hospital of Liège, Liège, Belgium

BACKGROUND. Cultured keratinocytes may represent an alternative therapy aiming at boosting leg ulcer healing. There is no evidence-based study comparing objectively the healing rate of splitulcer portions covered or not covered by cultured keratinocytes. OBJECTIVE. To assess the effect of cultured keratinocytes on the healing rate of leg ulcers.

METHOD. Five applications of fresh (cela, XCELLentis, Ghent, Belgium) or frozen (CryoCeal, XCELLentis) cultured allogeneic keratinocytes were performed at weekly intervals to treat large leg ulcers (mean diameter $>5 \mathrm{~cm}$ ) in four patients. A split-ulcer study was designed to secure a control area covered only by petrolatum gauze. Clinical, planimetric, bacteriologic, and immunohistologic assessments of the keratinocyte-treated and control parts of the ulcers were performed.
RESULTS. Compared with controls, planimetry revealed a beneficial effect afforded by cryopreserved cultured keratinocytes on the ulcer healing rate of two of four ulcers $(+12$ and $81 \%)$. The healing effect was obtained on the ulcers associated with the lowest bacterial load. Cultured keratinocytes did not qualitatively and quantitatively modify the ulcer biocenosis. They did not affect the number of any type of inflammatory cells present in the granulation tissue (type I dermal dendrocytes, macrophages, $\mathrm{T}$ lymphocytes, granulocytes). No specific side effect of cultured keratinocytes was evidenced.

CONCLUSION. In this small case series, it appears that cultured allogeneic keratinocytes may be helpful in the healing process of venous leg ulcers. However, a clean wound with reduced bacterial load seems to be the prerequisite condition for obtaining a beneficial effect.

THIS WORK WAS SUPPORTED BY GRANTS FROM THE FONDS D'INVESTISSEMENT DE LA RECHERCHE SCIENTIFIQUE OF THE UNIVERSITY HOSPITAL OF LIĖGE AND FROM INNOGENETICS, GHENT, BELGIUM.

CULTURED ALLOGENEIC keratinocytes have been advocated for years for the treatment of chronic leg ulcers of various origins. ${ }^{1-4}$ Graft rejection is not a problem because cultured keratinocytes exhibit low immunogenicity. Cultured keratinocytes probably produce a large repertoire of cytokines, adhesion molecules, growth factors, and basement membrane components able to modulate wound healing. ${ }^{5-7}$ Cultured keratinocytes may exert some antimicrobial activity through a mechanism of innate immunity, probably involving the release of antibiotic peptides. ${ }^{8}$ Such an activity might be important because microorganisms of many species are often abundant in chronic leg ulcers. ${ }^{9}$ At a critical contamination level, this enriched biocenosis can impede the healing process. ${ }^{10-12}$

The histologic changes in the wound bed following application of cultured keratinocytes have not been thor-

Address correspondence and reprint requests to: Gérald E. Piérard, MD, PhD, Department of Dermatopathology, CHU Sart Tilman, B4000, Liège, Belgium, or e-mail gerald.pierard@ulg.ac.be. oughly studied so far. We presently report a split-ulcer pilot study comparing the healing rate under the influence of fresh or frozen cultured allogeneic keratinocytes. We also describe the changes in different cell populations in the wound bed and the evolution in the composition and amount of the bacterial flora.

\section{Materials and Methods}

This open-label, randomized pilot study was conducted in accordance with the Declaration of Helsinki (1996) and its subsequent amendments. The protocol was approved by the local ethics committee. A written informed consent was obtained from each patient at the screening visit.

Four women aged 61 to 83 years were enrolled. They suffered from chronic venous leg ulcers that were unresponsive to conventional medical care for at least 3 months. The ulcers had an average diameter greater than $5 \mathrm{~cm}$ but did not extend to the fascia. No signs of microbial infection were present. Venous insufficiency of the affected leg was demonstrated using duplex ultrasonogra- 
phy and by the presence of hyperpigmentation or varicosities in the surrounding skin. One patient (patient 1) was taking immunosuppressive medication in moderate doses following a liver transplant in 1996.

During a 2 -week run-in period, the wound care performed by a specialized nurse consisted of alginate, hydrocolloid, foam, or hydrogel dressings according to the appearance of the ulcer. The ulcer was then again evaluated to ensure that the open wound area had not increased or decreased by more than $30 \%$ during the 2 -week run-in period.

Prior to application of the study products, ulcers were débrided and cleaned by gently dripped sterile saline. Other cleansers were not used. At week 0 , the randomized investigational products were applied for the first time on half of the ulcer. The other half part was covered by petrolatum gauze only. An absorbent pad and a compression bandage (Rosidal, Stella, Chenee, Belgium) were applied and left in place for 7 days. The study treatment was reapplied weekly for 4 consecutive weeks. Safety was evaluated by recording adverse events at each study visit: clinical evaluation (ulcer aspect, vital signs, physical examination), laboratory assessments (hematology, biochemistry), and bacterial evaluations by swabs.

Photographs and wound tracings were performed at weeks $-3,-1,0,2,4,6$, and 8 . The areas of the keratinocyte-treated and control parts was measured using computerized planimetry (Mop Videoplan Kontron, Eiching, Germany) of surface tracing drawn on plastic sheets, using a previously described method. ${ }^{11,13,14}$ The rate of healing or extension of the leg ulcers at completion of the treatment was measured using the healing index. Healing index adjusted to the initial perimeter (HIP, mm), was calculated as follows:

$$
\text { HIP }=\frac{\text { actual ulcer area }- \text { initial ulcer area }}{\text { initial perimeter }}
$$

The histologic aspects of the ulcers were assessed on $3 \mathrm{~mm}$ punch biopsies taken at weeks $0,2,4$, and 6 in the center of each half part of the ulcers. Histology and immunohistochemistry were performed (Table 1). Computerized image analysis was used to quantify the different cell populations in the superficial and deep parts of the granulation tissue. A mean percentage of the area occupied by the different populations in the corresponding tissue was established in three representative microscopic fields. These measurements were performed by one single-blind investigator.

Wound swabs on keratinocyte-treated and control parts were performed at weeks 0 and 6 for culture and Gram stain examination. Semiquantitative evaluations of the bacterial flora were assessed each time by the same microbiologist.

\section{Results}

\section{Leg Ulcer Planimetry}

Planimetry data are summarized in Table 2. The effect of treatment showed large interindividual variability. At completion of the study, a positive effect was noticed in two of four patients who experienced a $12 \%$ and an $81 \%$ greater HIP on the CryoCeal-treated part, respectively (Figures 1 and 2). No beneficial effect of keratinocyte grafts was recorded on the ulcer size in the two other patients.

Table 1. Panel of Antibodies

\begin{tabular}{lccc}
\hline Antibody & Source & Dilution & Specificity \\
\hline Mo, UCHL-1 anti-CD45R0 & Dako & $1 / 100$ & Mature T cells \\
Po, anti-factor XIIla & BioGenex & $1 / 300$ & Type I dendrocytes \\
Mo, anti-CD15 & Dako & $1 / 50$ & Granulocytes \\
Mo, Mac 387, anti-L1 & Dako & $1 / 100$ & Monocytes/macrophages \\
\hline
\end{tabular}

Mo = monoclonal; Po = polyclonal.

Table 2. Ulcer Healing Characteristics in a Split-Ulcer Design

\begin{tabular}{|c|c|c|c|c|}
\hline \multirow[t]{2}{*}{ Patient/Age, yr } & \multirow{2}{*}{$\begin{array}{c}\text { Keratinocyte-Treated Area, } \\
\text { HIP }(\mathrm{mm}), \mathrm{D} 42\end{array}$} & \multirow{2}{*}{$\begin{array}{l}\text { Control Area, } \\
\text { HIP }(m m), D 42\end{array}$} & \multicolumn{2}{|c|}{ HIP Difference } \\
\hline & & & $m m$ & $\%$ \\
\hline $1 / 79$ & Proximal Ceal +7.4 & Distal +5 & +2.4 & +48 \\
\hline $2 / 61$ & Proximal CryoCeal +5.3 & Distal -0.8 & +6.1 & +610 \\
\hline $3 / 75$ & Distal CryoCeal -4.7 & Proximal -4.2 & -0.5 & -12 \\
\hline $4 / 83$ & Proximal Cryoceal -4 & Distal -2.2 & -1.8 & -81 \\
\hline
\end{tabular}

$\mathrm{D}=$ day; HIP 


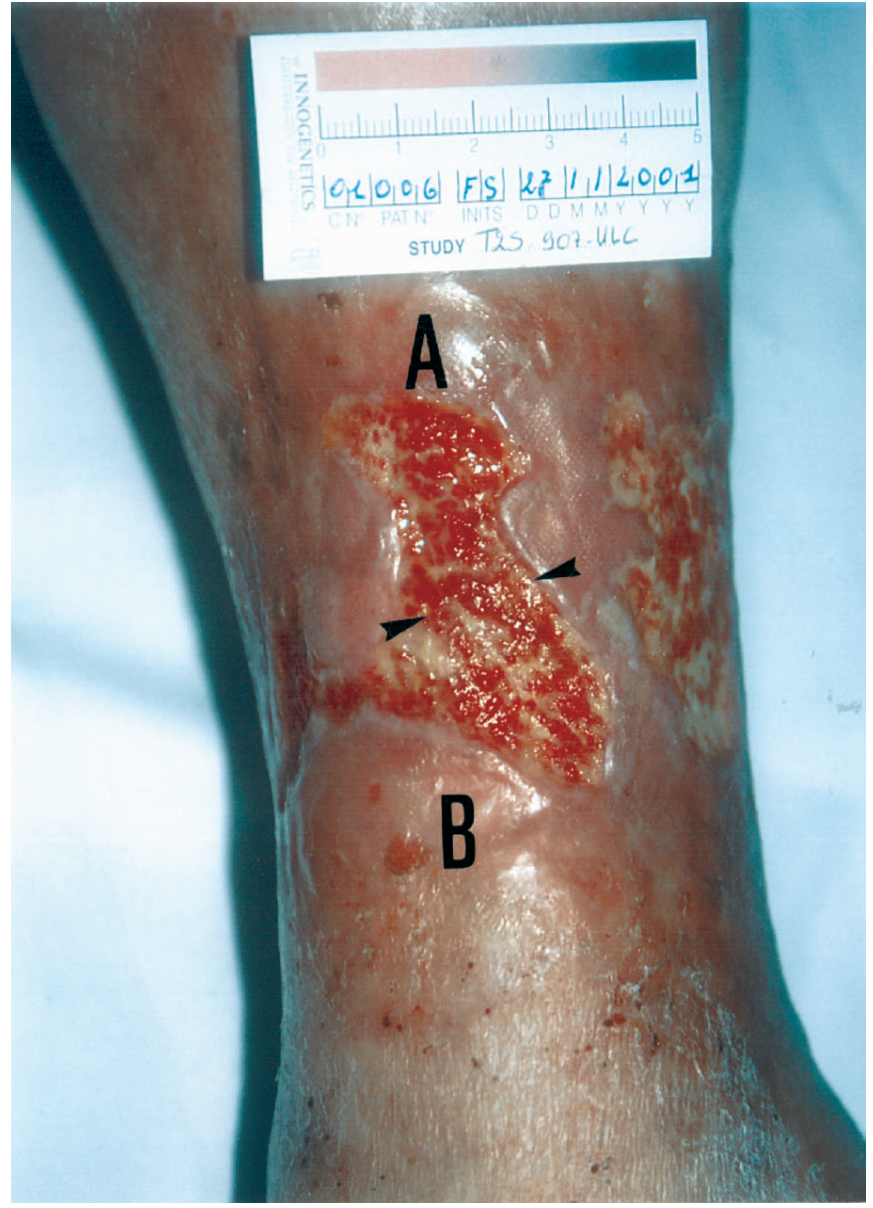

Figure 1. Leg ulcer in patient 4 at inclusion.

\section{Histology and Immunohistology}

All biopsy specimens taken from each half part of the ulcers before and during the study showed granulation tissue with inflammatory cells and discrete vasculitis in both the keratinocyte-treated and control parts of the ulcers. No difference was correlated with the clinical evolution of the ulcers. Compared with the control areas, no specific influence of keratinocyte grafts was observed on the different cell populations in the superficial or deep granulation tissue (Table 3). The healing propensity of the ulcers seemed to be clearly associated with a greater number in factor $\mathrm{XIII}^{+}$dendrocytes combined with a moderate number of $\mathrm{Mac} 387^{+}$macrophages in the superficial part of the granulation tissue and rare $\mathrm{CD} 15^{+}$granulocytes. No relationship was found between the number of $\mathrm{CD} 45 \mathrm{RO}^{+} \mathrm{T}$ lymphocytes and the healing rate.

\section{Microbiology}

Healing ulcers in two patients were clearly associated with a lower bacterial load at baseline (Table 4). The qualitative standpoint revealed a limited number of Staphylococcus

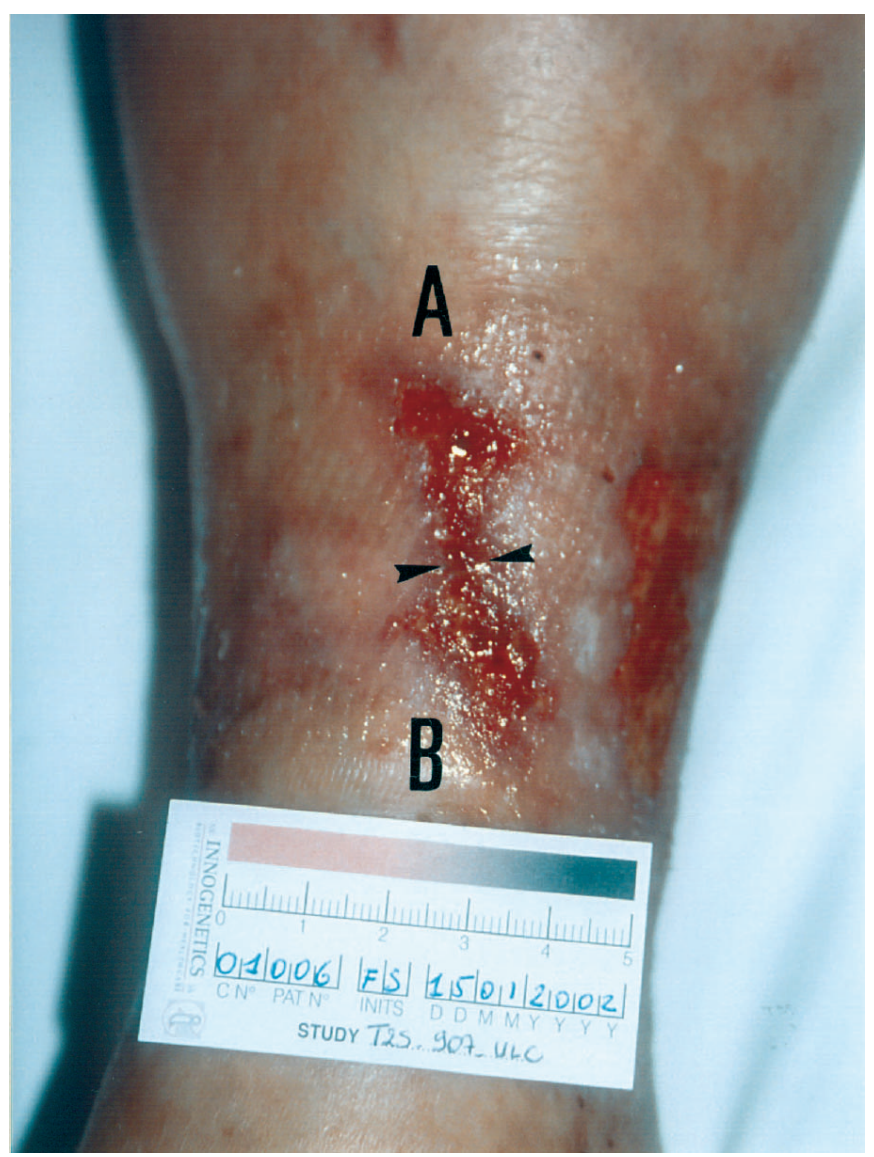

Figure 2. Leg ulcer of patient 41 week after completion of the splitulcer treatment. The CryoCeal-treated part (A) shows a reduction in size that is $81 \%$ superior to the evolution at the control site (B) covered by petrolatum gauze only.

aureus and the absence of both Enterococcus faecalis and Pseudomonas aeruginosa on healing wounds. In the two other patients, cultured keratinocytes did not prevent the growth of bacterial strains such as Escherichia coli and E. faecalis.

\section{Safety}

No safety issues were recorded during the study period.

\section{Discussion}

The effect of cultured keratinocytes on leg ulcer healing was often assessed in prospective, open, uncontrolled studies. In all trials, more meticulous medical care, including the correct use of compression bandages and rest in bed after grafting, likely improved the leg ulcer, irrespective of the effect of keratinocyte grafting. Only one study used a control group of patients distinct from those receiving the cultured cells. ${ }^{2}$

In the present pilot study, a split-ulcer design was used to secure a control area only covered by petrolatum gauze. 
Table 3. Relative Area (\%) Covered by Immunoreactive Inflammatory Cells

\begin{tabular}{|c|c|c|c|c|c|c|c|c|c|c|c|c|}
\hline \multirow{3}{*}{ Antibody/Patient } & \multicolumn{6}{|c|}{ Keratinocyte-Treated Area } & \multicolumn{6}{|c|}{ Control } \\
\hline & \multicolumn{2}{|r|}{ DO } & \multicolumn{2}{|c|}{$D 42$} & \multicolumn{2}{|c|}{ Difference } & \multicolumn{2}{|c|}{ DO } & \multicolumn{2}{|c|}{$D 42$} & \multicolumn{2}{|c|}{ Difference } \\
\hline & Sup & Deep & Sup & Deep & Sup & Deep & Sup & Deep & Sup & Deep & Sup & Deep \\
\hline FactorXIIIa & 0.5 & 5.9 & 0.6 & 8.4 & 0.1 & 2.5 & 4.1 & 2.2 & 0.5 & 10.1 & -3.6 & 7.9 \\
\hline 1 & 9 & 8 & 2 & 0.5 & -7 & -6.5 & 1 & 0.2 & 3.9 & 0.2 & 2.9 & 0 \\
\hline 2 & 0.4 & 0.4 & 6 & 5.9 & 5.6 & 5.4 & 0.5 & 1.1 & 8.3 & 6 & 7.8 & 4.9 \\
\hline 3 & 10.2 & 7.6 & 9.3 & 4 & -0.9 & -3.6 & 14.2 & 7.2 & 9 & 3 & -5.2 & -4.2 \\
\hline \multicolumn{13}{|l|}{4} \\
\hline \multicolumn{13}{|l|}{ CD45R0 } \\
\hline 1 & 4 & 4 & 5 & 5 & 0 & 0 & 9 & 10 & 9.8 & 3.8 & 0.8 & -6.2 \\
\hline 2 & 13 & 12 & 0.1 & 0.1 & -12.9 & -11.9 & 27 & 47 & 15 & 14 & -12 & -33 \\
\hline 3 & 5.2 & 4.9 & 0.5 & 1 & -4.7 & -3.9 & 4 & 5 & 4 & 5 & 0 & 0 \\
\hline 4 & 5 & 0.5 & 8 & 4 & 3 & 3.5 & 4 & 2 & 6.5 & 3 & 3.5 & 0.5 \\
\hline \multicolumn{13}{|l|}{ CD15 } \\
\hline 1 & 8 & 6 & 10 & 6 & 2 & 0 & 7 & 7 & 9 & 4 & 2 & -3 \\
\hline 2 & 15 & 30 & 15 & 25 & 0 & -5 & 22 & 27 & 24 & 24 & 2 & -3 \\
\hline 3 & 6 & 9 & 2 & 1 & -4 & -8 & 7 & 5 & 7 & 3 & 0 & -2 \\
\hline 4 & 5 & 0.1 & 7 & 1.5 & 2 & -1.4 & 3 & 0.1 & 3.5 & 0.2 & 0.5 & 0.1 \\
\hline \multicolumn{13}{|l|}{ Mac 387} \\
\hline 1 & 22 & 20 & 23 & 19 & 1 & -1 & 20 & 19 & 19 & 25 & -1 & 6 \\
\hline 2 & 35 & 30 & 14 & 9 & -21 & -21 & 65 & 58 & 27 & 20 & -38 & -38 \\
\hline 3 & 15 & 15 & 11 & 15 & -4 & 0 & 14 & 14 & 17 & 16 & 3 & 2 \\
\hline 4 & 20 & 5 & 11 & 8 & -9 & 3 & 17 & 17 & 11 & 9 & -8 & 6 \\
\hline
\end{tabular}

Sup = superficial.

Table 4. Ulcer Biocenosis before (D0) and after a 42-Day Treatment (D42)

\begin{tabular}{|c|c|c|c|c|}
\hline \multirow[t]{2}{*}{ Patient } & \multicolumn{2}{|c|}{ Keratinocyte-Treated Area } & \multicolumn{2}{|c|}{ Control Area } \\
\hline & DO & D42 & DO & D42 \\
\hline 1 & $\begin{array}{l}\text { Pseudomonas aeruginosa ++ } \\
\text { Staphylococcus aureus ++ }\end{array}$ & $\begin{array}{l}P . \text { aeruginosa }+++ \\
\text { Enterococcus faecalis }++\end{array}$ & $\begin{array}{l}\text { P. aeruginosa ++ } \\
\text { S. aureus ++ }\end{array}$ & E. faecalis ++ \\
\hline 2 & $\begin{array}{l}\text { Escherichia coli ++ } \\
\text { E. faecalis }++\end{array}$ & $\begin{array}{l}\text { E. coli +++ } \\
\text { Acinetobacter calcoa } \\
\text { Bacillus anitratus +++ }\end{array}$ & $\begin{array}{l}\text { E. coli }++ \\
\text { E. faecalis }++\end{array}$ & $\begin{array}{l}\text { E. coli }++ \\
\text { A. calcoa } \\
\text { B. anitratus +++ }\end{array}$ \\
\hline 3 & $\begin{array}{l}\text { Klebsiella oxytoca + } \\
\text { S. aureus + }\end{array}$ & $\begin{array}{l}\text { Proteus mirabilis } \pm \\
\text { S. aureus } \pm \\
\text { Group G streptococcus } \pm\end{array}$ & $\begin{array}{l}\text { K. oxytoca + } \\
\text { S. aureus + }\end{array}$ & $\begin{array}{l}\text { P. mirabilis + } \\
\text { S. aureus + } \\
\text { Group G streptococcus + }\end{array}$ \\
\hline 4 & S. epidermidis \pm & Coagulase-negative staphylococcus \pm & S. epidermidis \pm & Various gram + bacteria \pm \\
\hline
\end{tabular}

Number of colonies at culture: $\pm=$ few; $+=$ moderate $;++=$ numerous $;+++=$ abundant.

Two of the four ulcers appeared to benefit from the keratinocyte graft. In these cases, a positive edge effect of the cultured keratinocytes on the untreated area cannot be ruled out. Hence, the healing rate difference was probably greater than that measured. The positive effect on healing was obtained with cryopreserved keratinocytes, suggesting that frozen cultured sheets retained some healing potential on ulcers that were the least colonized by microorganisms. It is possible that a prerequisite condition for greater keratinocyte graft effectiveness is a low bacterial ulcer load. Even if innate immunity expressed by cultured keratinocytes exhibits inhibitory effects on bacterial growth in vitro, ${ }^{8}$ such a property cannot fully control a critical bacterial colonization in vivo in the particular environ- 
ment of a leg venous ulcer. ${ }^{9}$ Hence, an appropriate pregrafting preparation of the ulcer bed would probably benefit from antiseptics, stopping their applications just before grafting to avoid toxicity on the cultured cells. ${ }^{15,16}$ The nature of the bacteria present in the ulcers is also important. The classic pathogenic strains of pyogenic cocci $(S$. aureus, Enterococcus) and enteric gram-negative microorganisms (Pseudomonas and E. coli) produce exotoxins, leading to severe inflammation and tissue necrosis. ${ }^{15}$

In some of our patients, cultured cells had a significant effect on the amount of inflammatory cells, including factor $\mathrm{XIIIa}^{+}$dendrocytes, $\mathrm{CD} 15^{+}$granulocytes, Mac $387^{+}$ macrophages, and CD45RO ${ }^{+} \mathrm{T}$ lymphocytes. However, an effect on the functional capacities of these cells cannot be ruled out. Histologically, the healing process was associated with both an increased number of factor $\mathrm{XIIIa}^{+}$dendrocytes and a decreased number of granulocytes and macrophages. The nonhealing ulcers did not show these features. Factor XIIIa ${ }^{+}$dendrocytes share phagocytic and antigen-presenting properties. ${ }^{17,18}$ They also release some cytokines and growth factors contributing to the formation of the granulation tissue. ${ }^{17}$ Infiltrating neutrophils and macrophages can also help clean the wounded areas, fragments of extracellular matrix, and bacteria. ${ }^{6,7}$ Macrophages are able to produce various growth factors and cytokines, which may prove to be deleterious on healing. The decreased number of infiltrating neutrophils and macrophages in healing conditions is probably associated with a cleaner wound bed and decreased inflammation, helping reepithelialization. ${ }^{6,7}$

In conclusion, the results of this small case series are comparable with those obtained with other bioengineered skin material. Even if no firm conclusions can be drawn from this limited controlled pilot study, a moderate effect of allogeneic cultured keratinocytes on the healing of venous leg ulcer was seen in some cases. A clean wound with a limited bacterial load seems to be a prerequisite condition for a positive effect. Cultured allogeneic keratinocytes appear to be unable to down-regulate a critical bacterial colonization or to significantly modify the nature and amount of the cellular infiltrate in the granulation tissue. Future studies might take into account lateral side by side placement of the test material on the skin defect, as well as the use of fresh and cryopreserved cells and differing bacterial loads.

\section{References}

1. Teepe RGC, Roseeuw D, Hermans J, et al. Randomized trial comparing cryopreserved cultured epidermal allografts with hydrocolloid dressings in healing chronic venous ulcers. J Am Acad Dermatol 1993;29:982-8.

2. Lindgren C, Marcusson JA, Toftgard R. Treatment of venous leg ulcers with cryopreserved cultured allogeneic keratinocytes: a prospective open controlled study. Br J Dermatol 1998;139:271-5.

3. Bolivar-Flores YJ, Kari-Harcuh W. Frozen allogenic human epidermal cultured sheets for the cure of complicated leg ulcers. Dermatol Surg 1999;25:610-7.

4. Harvima IT, Virnes S, Kauppinen L, et al. Cultured allogenic skin cells are effective in the treatment of chronic diabetic leg and foot ulcers. Acta Derm Venereol 1999;79:217-20.

5. Phillips TJ. New skin for old. Developments in biological skin substitutes. Arch Dermatol 1998;134:344-9.

6. Singer AJ, Clarck RAF. Cutaneous wound healing. N Engl J Med 1999;341:738-46.

7. Quatresooz P, Henry F, Paquet P, et al. Deciphering the impaired cytokine cascades in chronic leg ulcers. Int J Mol Med 2003;11:411-8.

8. Maier K, Ehrhardt G, Frevert J. Antibacterial activity of cultured human keratinocytes. Arch Dermatol Res 1992;284:119-21.

9. Brook I, Frazier EH. Aerobic and anaerobic microbiology of chronic venous ulcers. Int J Dermatol 1998;37:426-8.

10. Robson MC, Stenberg BD, Heggers JP. Wound healing alterations caused by infection. Clin Plast Surg 1990;17:485-92.

11. Piérard-Franchimont C, Paquet R, Arrese JE, Piérard GE. Healing rate and bacterial necrotizing vasculitis in venous leg ulcers. Dermatology 1997;194:383-7.

12. Fumal I, Braham C, Paquet P, et al. The beneficial toxicity paradox of antimicrobials in leg ulcer healing impaired by a polymicrobial flora: a proof-to-concept study. Dermatology 2002;204 Suppl 1:79-85.

13. Deleixhe-Mauhin F, Piérard GE, Piérard-Franchimont C, et al. A morphometric analysis of the healing rate of ulcerations on atrophie blanche during simple nursing care. Eur J Dermatol 1991;1:101-4.

14. Piérard GE, Piérard-Franchiont C. Planimetry of the healing rate of leg ulcers. Eur J Dermatol 1995;5:257-62.

15. Niedner R, Schöpf E. Wound infections and antibacterial therapy. In : Westerhof W, editor. Leg ulcers, diagnosis and treatment. Amsterdam: Elsevier Science Publishing; 1993. p. 293-303.

16. Niedner R. Cytotoxicity and sensitization of povidone-iodine and other frequently used anti-infective agents. Dermatology 1997;195 Suppl 2:89-92.

17. Nestle FO, Filgueira L, Nickoloff B, Burg G. Human dermal dendritic cells process and present soluble protein antigens. J Invest Dermatol 1998;110:762-6.

18. Hermanns-Lê T, Paquet P, Piérard-Franchimont C, et al. Regulatory function of factor XIIIa positive dendrocytes in incipient toxic epidermal necrolysis and graft-versus-host reaction. Dermatology 1999;198:184-216. 